ECONOMIC THEMES (2019) 57(4): 459-480

\title{
LEGAL NATURE AND ROLE OF SWAP ARRANGEMENTS AND OPTIONS AS FINANCIAL INSTRUMENTS
}

\author{
Ružica Petrović \\ MSc student at University of Niš, Faculty of Law, Republic of Serbia \\ $\bowtie$ petrovicruzica30@gmail.com
}

Tamara Milenković Kerković

University of Niš, Faculty of Economics, Republic of Serbia

$\bowtie$ salamanca@eunet.rs

\section{Dragana Radenković Jocić}

University of Niš, Faculty of Economics, Republic of Serbia

$\bowtie$ draganarj61@gmail.com

UDC

336.76

347.440

Review paper

Received:

4.12.2019

Accepted:

9.1.2020

\begin{abstract}
Financial derivatives are, in the last forty years, the mos important financial innovation that influence the creation of new, very dee! and broad financial markets. Their number is constantly increasing. There i: a creation of new variants of existing derivative contracts and therefore the subjects have the opportunity to differently manage risk. Although thei: controversial legal nature, generally accepted view is that they wer contracts. Swap is the youngest of all financial derivatives and represents : financial innovation of a later date. Market swaps recorded one of the fastes growth rate among global financial markets. Swap represents a privat agreement between the two parties regarding exchange cash flow of the fixer time in the future in accordance with a predetermined pattern. The mos common users of swaps are non-financial corporations, which want to receivi variable, and to pay a fixed interest rate in order to limit interest expenses or bank loans or bond issues with variable interest rate, as well as banks, the governments of some supranational institutions such as the World Bank. Ir economic theory emphasized is the view that the comparative advantage is the basis for swaps functioning. Options are contracts in which one party ha: the exclusive right, while the other contracting party assumes only the obligation to buy or sell assets to which the option is created. In the nationa legislation the option contract is transferable standardized contract bindins the buyer has the right to, including the payment obligation of the agree premium on the day or days of maturity specified in the contract.
\end{abstract}

Keywords: contract, financial derivatives, swaps, options, cash flow

JEL classification: K22, D53, E44 


\section{Introduction}

The first traces of modern futures and derivatives date from the time when tulips came from Turkey to Europe. It is not easy to imagine that a flower such as tulips was the cause of one of the biggest crashes in the history of the stock market and stock market business till then. Something like this happened in the Netherlands in the first half of the seventeenth century. The event is known as tulip mania. The tulips arrived in the Netherlands from Turkey long time ago, in 1593. At first, they had been used only for medical purposes and later they became a symbol of power and a very popular flower among the wealthy sections of society. The best evidence of this is the fact that the most famous, and at the same time the rarest, flower in 1624 reached the price of about 1,200 guilders, which was the cost of a smaller house. It is reported that at one point in the whole of the Netherlands there were only two bulbs of this flower and even 12 hectares of land were offered to them.

The bulb trade was becoming more and more attractive and important to traders. Initially, it was only traded in the summer and delivery and payment would be made as soon as the deal was completed. Later, trade begins throughout the year. Each flower had a specific number and label depending on the type and weight. In this way, tulips became standardized commodities and were traded on the stock exchanges in Rotterdam and Amsterdam. This was the time when the first futures were created. The business was closed in the present, and the delivery of goods and payment were made in the future. The first options appeared to indicate the right to buy a flower at a certain price when it really flourished, but without the obligation to do so, which differentiates them from futures where it was basic.

Considering the time period in which all this was happening, the great geographical discoveries, the overall social prosperity in the Netherlands and the development of many trading companies, we could say that the demand for tulips, as a symbol of prestige, increased as well as their the price. There were more and more people who wanted to get involved in the trade in tulips and prices continued to rise during 1636. The price of the rarest flower (known as Semper Augustus) reached around 5500 guilders. At the beginning of 1637 the price grew faster and faster. Some traders were unable to settle their debts and went bankrupt. The market was in trouble. Dealers were offering large quantities of tulips, but now there was no one else to buy them. Suddenly everyone started to sell them and prices dropped sharply. The price of one flower of a tulip dizzily dropped to the price of a single onion.

Although the roots of financial derivatives go so far in the past, they are relatively new financial instruments that have emerged and experienced expansion over the last forty years, in the midst of pursuing financial innovation. They have radically changed the financial markets of all countries, both the most developed and the developing ones. Derivatives have become much more than the instruments 
whose fate was uncertain, for which it was not known whether and when they would live on the financial markets around the world. They have become a concept and a prism through which the world of modern finance is viewed and without which it would not be sustainable.

\section{Swap arrangements and options - concept and legal nature}

\subsection{Swap arrangements}

Swap arrangements, in addition to being OTC derivatives, belong to the group of synthetic financial instruments. They are created by packing simpler financial instruments and contracts, or combining them.

Swap is the youngest of all financial derivatives and is a recent financial innovation. The first swap was created in 1981. The swap market is recording one of the fastest growth rates among global financial markets. The swap is a private agreement between the two parties to exchange cash flow at a fixed time in the future and in accordance with a pre-determined pattern (Marinković, 2011). Three dates are important in their realization:

1. the date when the terms and the swap agreement were concluded,

2. the start date of realization, from which interest rates start to be calculated,

3. the due date at which the settlement ends and the payment is made.

The most common beneficiaries of swaps are non-financial corporations who wish to receive variable interest and pay a fixed interest rate to limit interest rates on bank loans or variable interest rate bond issues, followed by banks, governments and some supranational institutions, such as the World Bank.

In order to prevent the possibility that a contracting party, due to financial difficulties, fails to fulfill its contractual obligations, a separate counterparty is often called into the swaps. These are brokers, known as swap dealers. Usually these are reputable and very stable organizations, most commonly known banks in the world.

Cash flow can be in similar or different currencies, so depending on that, we discern currency and interest rate swaps. In a currency swap, cash flow is exchanged in different currencies, while a swap in which both parties exchange money in identical currency, determined on the basis of a certain interest rate, is interest rate.

In the field of literature, agreement and contract are often used synonymously, and it does not matter whether we define swaps as agreements or contracts (Radovic et al., 2018). Legal science, on the other hand, indicates that there are differences between these institutes. In all countries, a contract is an agreement (agreement, consent of wills) of at least two persons, by which they agree to take 
certain actions or refrain from them. Not all agreements enjoy legal protection. An agreement that one legal system recognizes as a contract may not be recognized by another and may not provide legal protection (Jovanovic, 2008). It can be concluded that the agreement has less legal force than the contract. Every contract is an agreement, but not every agreement can be a contract. As the derivatives are still not sufficiently legally grounded and regulated, this issue is delicate and remains open to debate.

\subsection{Interest rate swap arrangement}

An arrangement swap implies that one contracting party undertakes to pay to the other party the cash flow obtained by applying a fixed interest rate to a specified nominal amount (contingent or accrued principal). At the same time, the other party undertakes to pay the first cash flow equal to the interest at a variable interest rate for the same nominal amount for the same period of time. Both cash flows are denominated in the same currency. Usually the duration of a swap arrangement is 2 to 15 years.

The flexible interest rate, which is found in most swap contracts, is the London Interbank Offer Rate (LIBOR), which is formed on the London interbank market on deposits of 1 month, 3 months, 6 months and 12 months. The amount of LIBOR depends on the term of depositing money with another bank.

The essence of this derivative can be pragmatically observed by a simple example:

In a situation where two legal entities (companies A and B) are in the status of debtors, but as contracting parties that realize contracts with different types of interest rates, it can be observed that they have a different market advantage. For example, one company will realize its debt at a variable interest rate, and another company will pay at a fixed interest rate. Considering their credit rating, the debt of both companies can be presented as follows:

Table 1: Debts of the two companies at different interest rates

\begin{tabular}{ccc}
\hline Company & $\begin{array}{c}\text { Fixed } \\
\text { interest rate market }\end{array}$ & $\begin{array}{c}\text { Variable } \\
\text { interest rate market }\end{array}$ \\
\hline A & $5 \%$ & LIBOR $+0,5 \%$ \\
B & $7 \%$ & LIBOR $+2 \%$ \\
Difference & $2 \%$ & $1,5 \%$ \\
\hline
\end{tabular}

Source: Erić, 2003

Thus, Company A has an absolute advantage in both markets (it can borrow at lower interest rates). At the same time, the conclusion is that the same company has 
a comparative advantage in the market with a fixed interest rate, which makes it different from the other company. On the other hand, Company B, as a comparative legal entity, has a comparative advantage in the market with a variable interest rate ("lag" relative to Company A is smaller, 1.5\%). In order to borrow as these companies intended to, they enter the swap:

Figure 1: Swap example

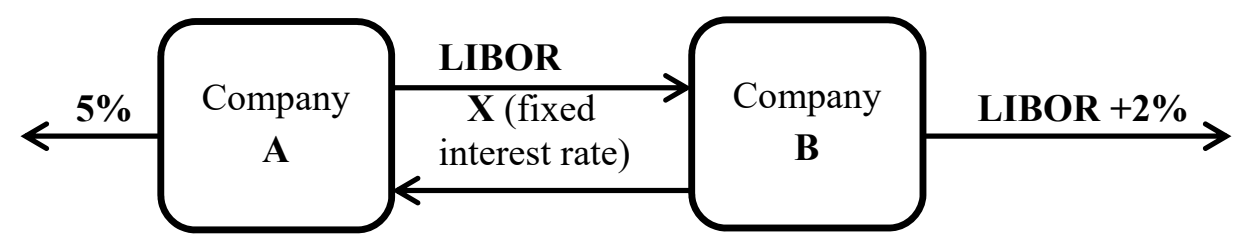

Source: Authors

Both legal entities, and both companies, will have an interest in a swap under certain conditions. First of all, it is necessary to determine the interval at which an unknown X can move, via two situations, when it is present in one swap and is not present in the other (Marinkovic, 2017). It is understood that the above facts are taken into account by comparing the above elements in both companies.

Figure 2: A chart showing the interest of the two companies in the swap

\begin{tabular}{|c|c|}
\hline \multicolumn{2}{|c|}{ Company A } \\
\hline with SWAP & without SWAP \\
\hline $5 \%$ & \\
+ & \\
LIBOR & LIBOR $+0.5 \%$ \\
- & \\
$X$ & \\
\hline $5 \%+$ LIBOR $-\mathrm{X}<$ LIBOR $+0.5 \%$ \\
\hline
\end{tabular}

\begin{tabular}{|c|c|}
\hline \multicolumn{2}{|c|}{ Company B } \\
\hline with SWAP & without SWAP \\
\hline LIBOR $+2 \%$ & \\
+ & \\
$\mathrm{X}$ & $7 \%$ \\
- & \\
LIBOR & \\
\hline \multicolumn{2}{|c|}{ LIBOR $+2 \%+\mathrm{X}-\mathrm{LIBOR}<7 \%$} \\
\hline
\end{tabular}

Source: Authors

These inequalities are formed to follow basic economic logic. Specifically, swap financing conditions should be more favorable than financing conditions without swap (hence the sign of inequality is $<$ ) (interpreted according to Marinkovic, 2017, pp.344-345).

Solving the first inequality gives the following result:

$$
\begin{gathered}
5 \%+\text { LIBOR }- \text { LIBOR }-0,5 \%<X \\
X>4,5 \%
\end{gathered}
$$


The result of the second inequality is:

$$
\mathrm{X}<5 \%
$$

Taking into account the values obtained, it follows:

$$
4.5 \%<\mathrm{X}<5 \%
$$

Provided that the entities agreed that Company B would pay Company A $4.75 \%$, then the entry into the swap would be equally payable to both parties. Both companies would make equal savings. Finally, by showing the situation with and without the swap if the fixed interest rate is $4.75 \%$, there is also a savings of $0.25 \%$ for both parties.

Figure 3: Swap shape without dealer mediation

\begin{tabular}{|c|c|}
\hline \multicolumn{2}{|c|}{ Company A } \\
\hline with SWAP & without SWAP \\
\hline $5 \%$ & \\
+ & \\
LIBOR & LIBOR $+0.5 \%$ \\
- & \\
$4.75 \%$ & \\
\hline
\end{tabular}

\begin{tabular}{|c|c|}
\hline \multicolumn{2}{|c|}{ Company B } \\
\hline with SWAP & without SWAP \\
\hline LIBOR + $\%$ & \\
+ & \\
$4.75 \%$ & $7 \%$ \\
- & \\
LIBOR & \\
\hline
\end{tabular}

Source: Authors

The example presented above is given in the simplest form, without the intervention of a swap dealer. How credit risk is transferred to him and how he guarantees the fulfillment of contractual obligations, his place and role in the swap is as follows:

Figure 4: Dealer-mediated swap shape

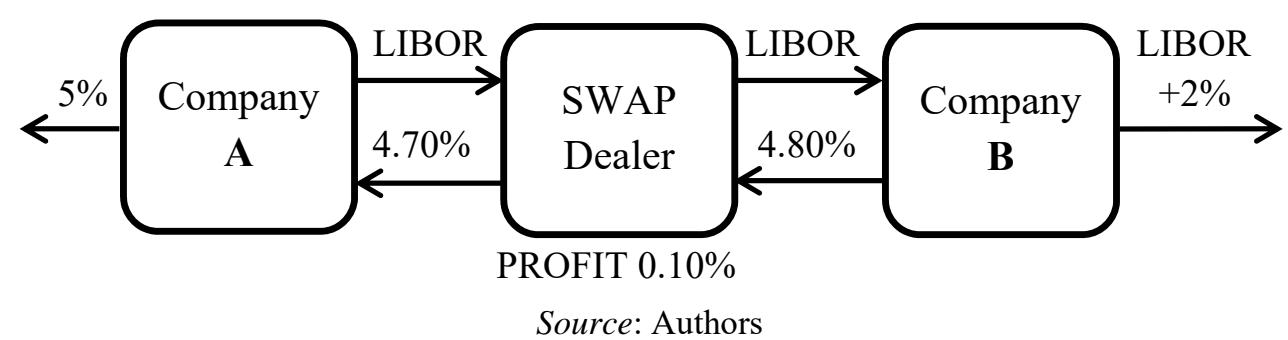




\subsection{Currency swap arrangement}

This type of swap implies the principal and the interest in one currency are exchanged for the principal and interest in the other currency. This type of swap was the first to be applied among subjects. The currency swap arrangement differs from the interest rate swap in that the principal swap is not exchanged, but is used solely for the purpose of calculating interest. For currency, the principal is exchanged at the beginning of realization and the maturity of the swap. The exchange rate at which interest and principal will be exchanged, expressed in both currencies, is determined according to the exchange rate at which the two currencies are exchanged on the spot market at the moment when the swap realization begins. A currency swap is used in two ways: the first is that it serves to manage currency risk, and the second relates to situations where there are obstacles to direct borrowing in certain currencies, for example, to control international capital movements. Even when it comes to borrowing obstacles, a swap can be a more cost-effective solution than directly borrowing some currency.

The implementation of a currency swap arrangement can be best viewed by comparing two companies, which are based in different countries, have different credit ratings and want to borrow in different currencies, one in pounds (British for which the debt in dollars is at the rate of $11 \%$ and in pounds $7.5 \%$ ), and the other in dollars (US - 10\% debt in dollars, $7.25 \%$ in pounds)

Assuming that both companies have access to the market, the one with the better credit rating will borrow at a lower interest rate. Also, this company has an absolute advantage in both markets, looking at the markets according to the countries where the companies are based. However, a British company that wants to borrow in pounds has a comparative advantage in borrowing in this currency. We can show how to create a swap with the following scheme:

Figure 5: Creating a currency swap arrangement

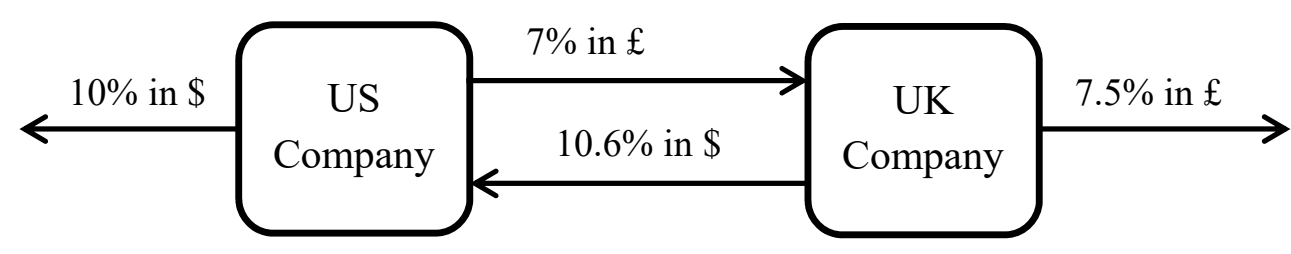

Source: Authors

The effects for the US and UK companies are calculated as the difference between the difference in interest rates on the pound and the dollar interest rate.

The effect for a US company:

$$
(10.6 \%-10 \%)-(7.25 \%-7 \%)=0.6 \%-0.25 \%=0.35 \%
$$


The effect for a British company:

$$
(7.5 \%-7 \%)-(11 \%-10.6 \%)=0.5 \%-0.4 \%=0.1 \%
$$

From the review, we can see that the US company, which has an absolute advantage in both markets, has a comparative advantage in debt in dollars.

\subsection{Credit risk swap}

This derivative, also known as Credit Default Swap (CDS), attracted a lot of attention at the time of global crisis eruption. It has allowed some investors to protect themselves from credit risk and overcome the crisis, while others have brought many difficulties. Although it is noted that it existed during the 1990s, the end of 1994 is taken as the time when it was first used. His creation is linked to the name Blit Masters, who was the leader of a group that was involved in the development of this swap at JP Morgan Investment Bank.

This swap also works on a similar principle as the others. The principal is the nominal value of the underlying instrument (usually a bond whose issuer is a private or public legal entity). Here, there is an exchange of cash flows, too but in a slightly different way. For a currency and interest rate swap, which party will make and receive the payment depends on the value of the financial variable defined in the contract. In the case of credit risk swaps, one party makes payments until the insured event occurs when the other party's obligation is carried out. The parties to the contract are the buyer and seller of credit insurance. The buyer undertakes to make a periodic payment of the agreed premium from the beginning of the realization of the swap to maturity or possibly to the insured event if it occurs, and the seller undertakes to buy from the buyer a defined amount of bonds at their nominal value (when it comes to delivery), or to pay the difference between the nominal value and the market price of the bonds. The insured case must be clearly specified, as it determines the moment when the obligation of the buyer terminates and the seller's obligation under this contract arises. The secured (credit) case is considered the default of bond issuers held by credit insurance buyers. The relations between the parties can be summarized as follows on Figure 6 (Erić \& Đukić, 2012):

The undoubted conclusion is that there is an agreement between the buyer and the seller of CDS in which the seller undertakes to compensate for the loss of the buyer in the event that the bond issuer, who the buyer has in his possession, fails to fulfill obligations under the credit instrument. The buyer agrees to pay the seller a premium, the amount of which is determined by applying the appropriate rate to the principal. The amount of the premium will depend on the amount of credit risk.

The beneficiaries of this type of swap are first commercial banks, then investment banks, while insurance companies are the most commonly reported sellers. 
Figure 6: Buyer and seller relationships in CDS

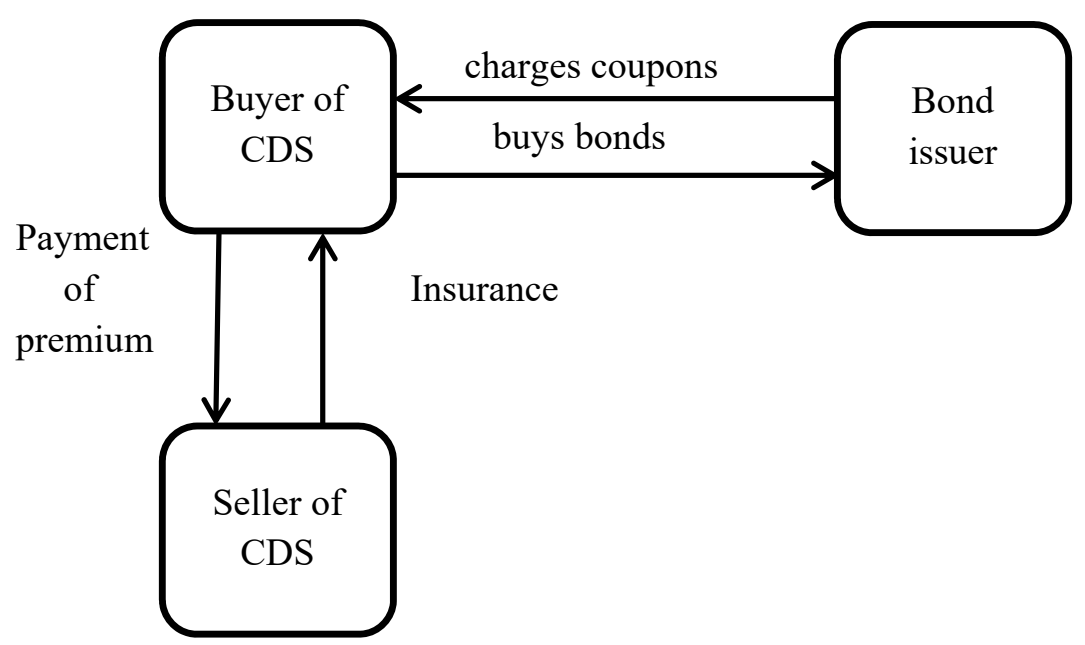

Source: Erić \& Đukić, 2012

\section{Why are there swaps?}

In economic theory, it is argued that comparative advantage is the basis for the functioning of swaps. This can be seen from the examples given earlier for interest rate and currency swaps. The reason for the existence of an interest rate swap is the comparative advantage arising from the imperfection of the market. If the market were perfect, the credit rating of the counterparties would be identical regardless of who makes that assessment. In this case, the existence of a swap would be redundant and would not have positive effects on either side; neither of the parties would make savings from entering the swap. Due to the fact that in different markets, the same borrowers have different credit risk premiums, there is room for parties to create swaps and borrow under more favorable conditions.

Another reason why some organizations use this derivative is the nature of the maturity structure of the balance sheet. Those entities that fund longer-term investments in short-term sources are exposed to interest rate risk. They run the risk that interest rates on sources will change every time they need to rebuild matured sources, and this must be done at the rates that are formed in the market at the time the sources are renewed. Due to the short-term sources, these organizations pay a variable interest rate, even when the original contracts set a fixed interest rate. They are matched by a swap in which they receive a variable interest and pay a fixed interest rate.

Also, highly indebted companies can hardly make long-term arrangements with fixed interest rates and then enter into a swap where they pay a fixed interest rate and receive a variable interest rate. 


\section{Options - concept and legal nature}

Options are contracts in which one party has the exclusive right, while the other party assumes the exclusive obligation to buy or sell the asset to which the option was created. The party that acquires the contract is called the buyer of the option, and the party assuming the obligation to fulfill the other party's requirements is called the seller (writer) of the option (Marinković, 2011). As the holder of the option has the right, but not the obligation, to perform the contractual exchange, buy or sell the underlying instrument, options are the only derivatives with an asymmetric position profile. For all other derivatives, both parties have a firm contractual obligation (symmetrical position profile). Because of this, the options are the most complex and the only derivatives traded on the stock market and overthe-counter (OTC) market.

If we take as a definition of options a slightly broader understanding related to the acquisition of a certain right by payment of remuneration or labor, then historically, traces of the first options are found in the Bible (Genesis, Chapter XXIX). The Book of Genesis contains events that took place around $1700 \mathrm{BC}$. According to the Bible, Jacob gained the right to marry Lavan's younger daughter, Rahily, while working for seven years. In other words he bought the option. On the day of his wedding, Jacob was told by Laban that he could only marry his older daughter, Leah, thereby preventing Laban from fulfilling his obligation to Jacob (risk of default). After marrying Leah, Jacob gained the right to marry Rahily through additional work of seven years. In the end, Jacob had two wives and twelve sons who became patriarchs of the twelve tribes of Israel (Erić \& Đukić, 2012).

There are records which suggest that in Ancient Greece the philosopher Thales bought the right to use olive presses during the winter period around $580 \mathrm{BCE}$. The press owner was pleased that he had earned income during the period when olive presses were not used. Due to favorable weather conditions, there was an unexpectedly good olive yield and consequently an increase in demand for presses. In such circumstances, the option holder was able to sell the right to use the press during the season at a price higher than the price he paid during the winter. The difference between the two prices represented the earnings for holder who had the right to do so. According to the same principle, it is now possible to make capital gains by trading options (Erić, Đukić, 2012).

Thus, it is possible to make a contract for the right to purchase at a certain price for a particular asset in the future by the option. Such an option is a call option. When the option contracts the right to sell to another party under predefined conditions, this option is called the put option (Milenković Kerković, 2009).

An option contract is a highly standardized contract that contains the following elements: 
- the type of asset or instrument to which the option relates; most commonly, these are ordinary shares where the name of the issuer of shares, the amount or number of shares that can be bought or sold, are also indicated;

- the agreed price, that is, the price at which an option buyer can buy or sell a specific asset;

- the maturity date, that is, the end date by which the option can be exercised.

The possibilities that the owner of the option has, according to Eric and Djukic (2012, p. 370) can be presented as follows:

Figure 7: Three scenarios by which an option owner is faced with

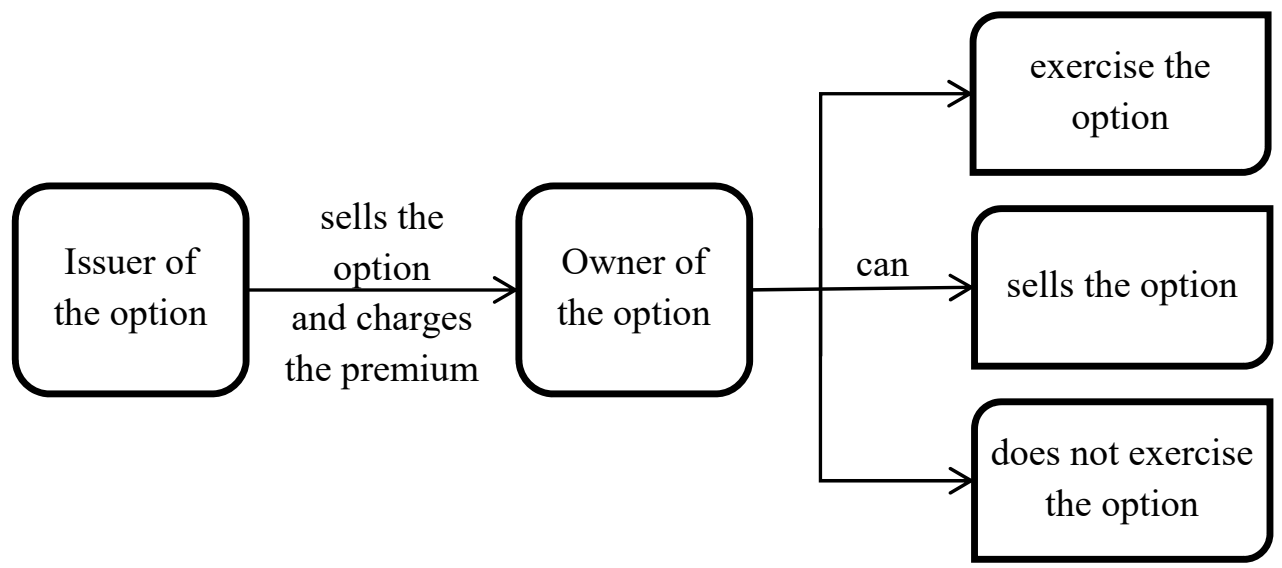

Source: Marinkovic, 2003

When purchasing options, the buyer pays a premium after which, as the owner, he is entitled to:

1. Exercise the option by exercising the right which he has as the owner by the act of buying or selling the underlying assets;

2. sells the option on the secondary market within the stock exchange or over-thecounter trade;

3. does not exercise the option, which means that he does not buy or sell the underlying assets within the stipulated time limit.

Which of these three options he will use depends on the movement of the underlying asset price and the contracted price in the contract.

In national law, an option contract is a transferable standardized contract whereby the buyer acquires the right to, with the obligation to pay the contractual premium on the day or maturity date specified in the contract, and the maturity date may not be less than three days from the date of conclusion of the contract - the price stipulated in the contract, and the seller assumes the obligation to sell or buy the object of the contractual obligation on that day (Article 24 of the Law on the 
Market of Securities and Other Financial Instruments). Although the law provides for the trading of these derivatives, they are not traded on the domestic capital market.

In theory, most dilemmas exist precisely about the legal nature of these derivatives. Even though the legislator defines them as contracts, the dilemma concerning what type of contracts they belong to is still present.

\subsection{Types of options and basic option strategies}

By the nature of the rights they contain, options can be call options and put options. A call option is a type of option that entitles the holder to buy a certain amount of the underlying instrument at a predetermined price until a predetermined date in the future. The holder of a purchase option that has paid the issuer a premium may purchase certain assets, which may take the form of goods, services or financial instruments. For the amount of premium paid, the option seller undertakes to execute the buyer's order, that is, to sell the asset to him at a predetermined price within the agreed period of time. The option seller is in a short position. When the market price of the underlying asset is higher than the contracted price, the purchase option is said to be of interest in monetization (in the money). When the market price of the underlying asset equals the contracted price for the purchase option, it is said to be close to the point of redemption (at the money).

The put option is the type of option that entitles the owner to sell the underlying asset at a pre-determined price until a certain day in the future. It enables the owner to hedge against the risk of a fall in the price of the underlying asset. The issuer, i.e. the seller of the option, which has earned income on the basis of the paid premium, is obliged to buy the underlying assets at the price specified in the contract. When the market price of the underlying asset is less than the contractual one, the sale option is said to be of interest (in the money). When the market price of the underlying asset equals the contracted price, the sale option is said to be close to the point of redemption (at the money). If the market price of the underlying asset is higher than the agreed price, the owner of the put option has no interest in exercising the right of sale (out of the money).

With these two basic types of options, the investor can be in the role of buyer or seller of each, so there are also four simplest options strategies.

a) Long call strategy

This strategy involves the position of the buyer or the owner of the purchase option. The investor's motive to buy the purchase option lies in the expectation that there will be an increase in the price of the underlying asset (for example a stock) and that he will earn a return on that basis. Investor profit is the difference between a higher market price and a lower contract price. For example, if an investor has the option to buy 100 shares of $\mathrm{AB}$ at a price of 40 currency units by 31 December, 
and if the current market price on 31 December is 50 cash units, then the option holder can make a profit of 10 currency units if he exercises the option and buys the shares at the agreed price of 40 currency units.

Figure 8: Long buying strategy

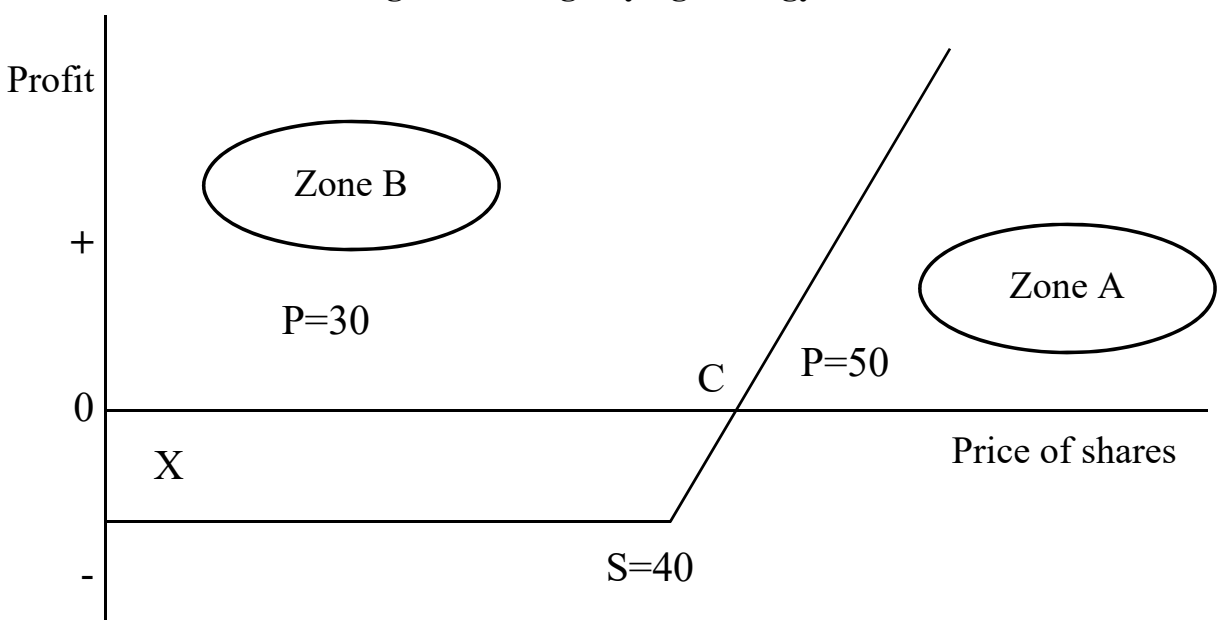

Source: Erić, 2003, p. 412

The analysis of the graph shows the conclusion that the current market price $(\mathrm{P}=50)$ is in zone $\mathrm{A}$ and is higher than the contracted price $(\mathrm{S}=40)$ and then it is said that the option has value or that it is "in the money". In this example, the case is that the owner will use the option, since it pays him to buy shares for 40 monetary units, which worth 50 in the market. However, we should bear in mind that the actual profit for the investor is not equal to the difference between the current and the agreed price (in the example of 10 currency units), since he has to buy the option, i.e. to pay the option seller a premium (Zone X), thus slightly reducing his profit.

If the market price of the shares is in zone B, or if it is less than the agreed $(\mathrm{P}<\mathrm{S})$, then the option is said to be "out of the money". If in our example the market price was 30 monetary units, it would be worthless to the investor and he would not use it.

Point $\mathrm{C}$ represents the case when the market and contracted prices are equal. It is then said that the option is "at the money". In our example, this would mean that $\mathrm{P}=\mathrm{S}=40$ monetary units.

\section{b) Short call strategy}

This strategy refers to the position of the buyer of the purchase option. Unlike the buyer, who expects the price of the underlying asset to rise, the seller expects the price of the underlying asset to fall. In the event that this happens, the option 
holder will not exercise the option, and the seller (the holder of the obligation) will remain net profit in the amount of the premium received by selling the option.

Figure 9: Short buying strategy

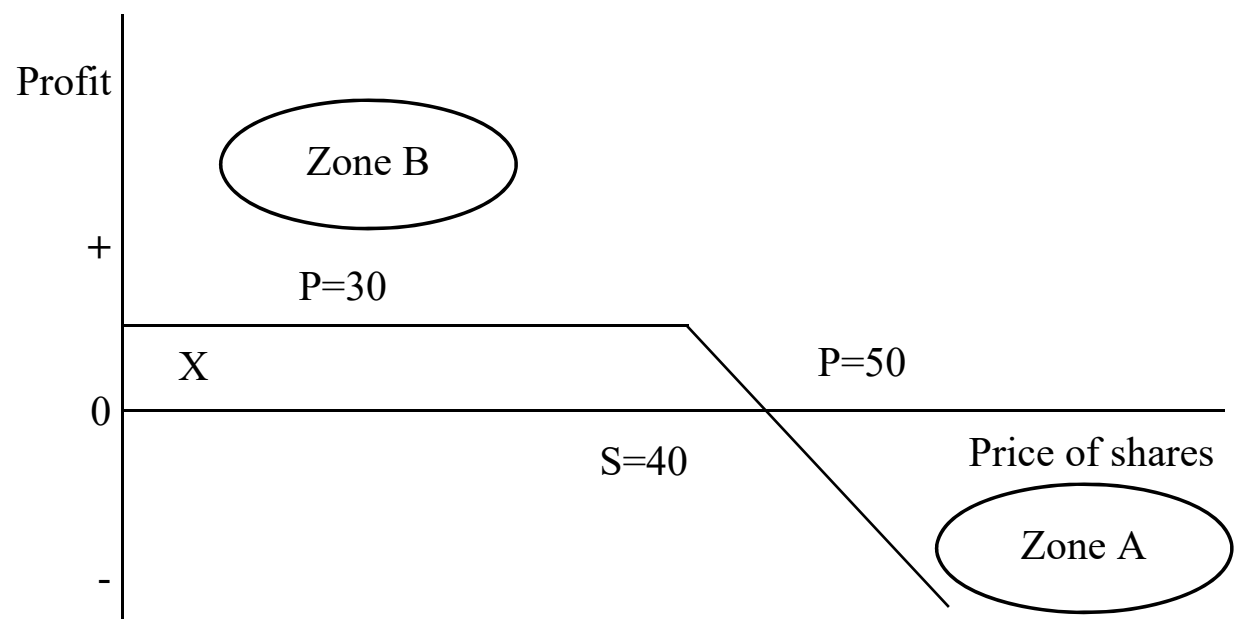

Source: Erić, 2003, p. 412

For the seller of the purchase option, the gain zone is zone B, because then the owner of the purchase option will not exercise the option. In this case, he makes a profit equal to the premium paid $(\mathrm{X})$. In case where the current price is higher than the contracted price $(\mathrm{P}>\mathrm{S}$, zone $\mathrm{A})$, the seller will suffer a loss equal to the difference between the current and contracted price (in our example 10 monetary units). So, he has to sell the stock to the buyer at a lower, agreed price of 40 monetary units. The loss for him increases as the stock market price rises. However, the actual loss is less than 10 monetary units because the seller collected a premium from the buyer when selling the option (X).

c) Long sales strategy (long put)

A long sales strategy involves the buyer's position of the sales (put) option. The basic motive of an investor to buy a put option is the ability to hedge against the risk of a fall in the price of the underlying asset. Namely, if the investor buys a sale option with the right to sell 100 shares of $\mathrm{AB}$ at the agreed price of 40 monetary units, with a deadline to December 31 and if the market price drops to 30 currency units, the owner will exercise the right and sell the shares to the option seller at the agreed price of 40 currency units. In case the market price is lower than the agreed price $(\mathrm{P}<\mathrm{S}$, zone $\mathrm{A}$ on the chart), the sale option is said to be "in the money". If the market price is higher than the contracted price $(\mathrm{P}>\mathrm{S}$, zone $\mathrm{B})$ this option is "out of the money" and the owner will not use it, as it can sell the shares on the market at a price higher than the contracted one $(\mathrm{P}=50)$. 
Figure 10: Long sales strategy

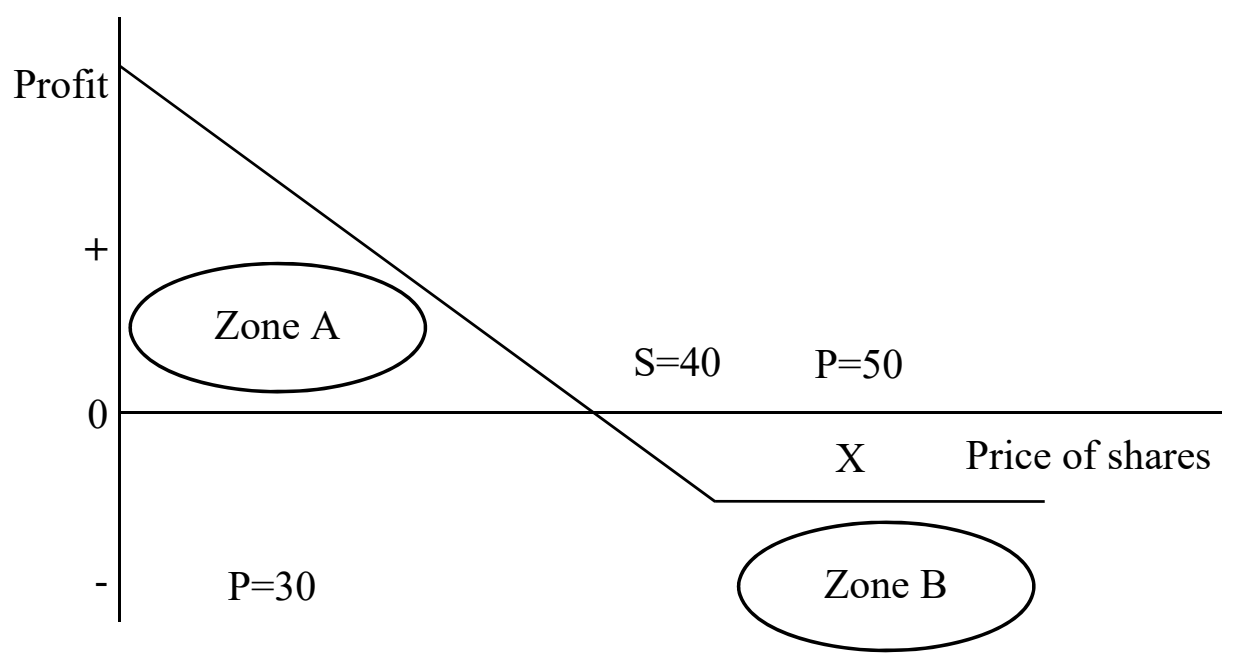

Source: Erić, 2003 (p. 413)

This strategy is a true example of using options as a hedging instrument. Although there are many possible hedging strategies today, investors who are risk averse are advised that when they buy an underlying asset (such as a stock), they immediately buy the put option at the same price. In this way, the risk is reduced because if the stock price falls, investors can recover the value of the initial investment by exercising the option.

d) Short sales strategy (short put)

Short put as a strategy is quite the opposite of long selling and refers to the seller's sales (put) options. Concerning a sell option, the seller expects the price of the underlying asset to rise. In this case, the owner of the put option will not exercise the option and the seller is left with a profit in the form of a premium received by selling the option. The seller can be sure that the option will not be exercised as long as the market price is higher than agreed $(\mathrm{P}>\mathrm{S})$. Then the owner of the option follows the logic- why to sell at a lower contracted price ( $\mathrm{S}=40$ in our example), when the shares can be sold on the stock market at a higher market price $(\mathrm{P}=50)$. So, the graph shows that zone B (in which the stock price rises) is the gain zone for the seller of the sale option. However, if the price of the underlying asset starts to fall below the agreed price of $S=40$, the option owner will call the seller and demand buying the shares at a price higher than the market price, thereby generating a loss. The loss equals the difference S - P. The amount of the loss increases as the price of the underlying asset falls faster. This loss is partially offset by the amount of premium paid $\mathrm{X}$. The maximum loss that a seller of a put option can make is equal to the 
contracted price minus the premium. It occurs if the price drops to zero $(\mathrm{P}=0, \mathrm{~S}-0$ $=\mathrm{S})$. So Zone A is a loss zone for him.

Figure 11: Short sales strategy

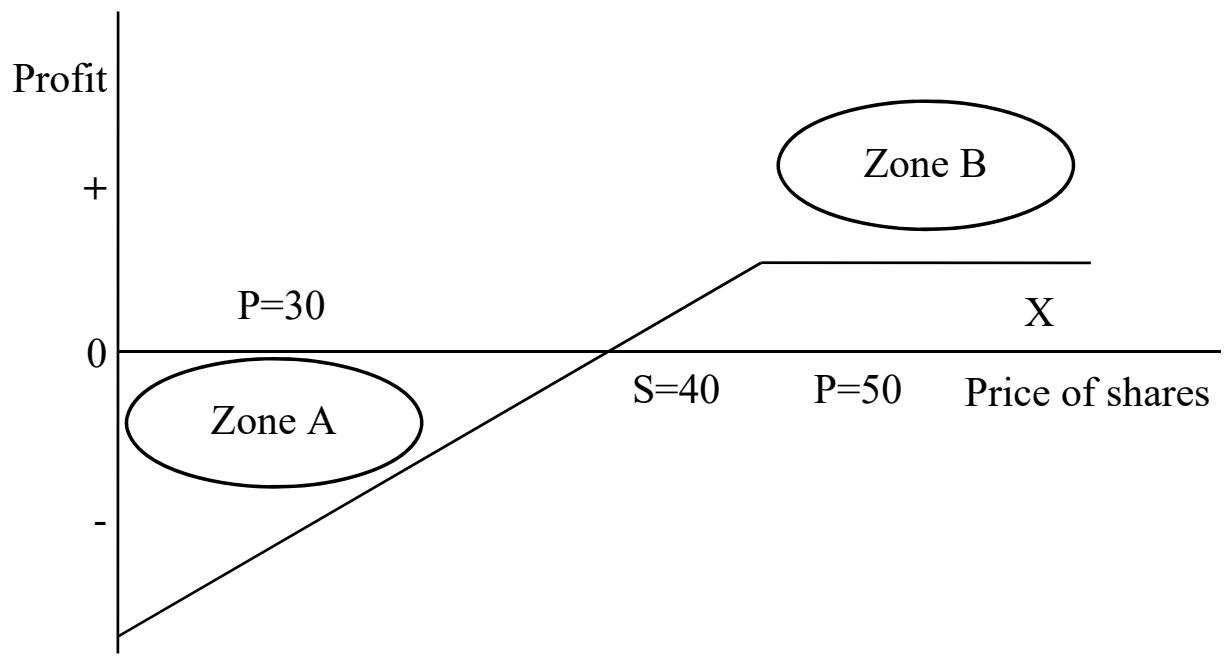

Source: Erić, 2003 (p.414)

Buying and selling options do not exist solely as a theoretical concept. Everyday practice shows numerous examples when subjects can be found in the role of seller or buyer, and when we are offered opportunities to use these options (Savic \& Veselinovic, 2019).

The option allocation method can be used as a criterion for splitting options. In this case, the options may be stock and non-stock options. OTC options are much older and had been in use for many years before the start of organized trading in Chicago options in 1973. As they are not standardized, they do not apply the margin system as with stock options. They are not liquid and are the result of private arrangements. Their basic features are:

- they are traded privately and through individual contracts;

- they are not standardized;

- $\quad$ prices are less transparent and more difficult to make publicly available;

- market participants need to know one another;

- can be concluded anytime, anywhere;

- less liquidity;

- open positions cannot be closed easily;

- many contracts end in physical distribution.

Basic features of stock options:

- trading is public; 
- a high degree of standardization;

- prices are highly transparent and made public;

- participants do not need to know each other;

- trading time is limited and stock market rules must be strictly adhered to;

- open positions can be easily closed by trading;

- high level of liquidity;

- a small number of transactions end in physical distribution.

Therefore, when it is possible to exercise a right from an option, at some point or until a certain moment, European and American options differ. When an option holder can exercise the right to a specific day, the option is European. This date is the due date of the option. The right from US options can be exercised throughout the period, from the moment of the conclusion of the contract until the last date. The last day that the right can be exercised then becomes the expiration date of the option. Due to this feature, US options cannot have a lower price than identical European ones. This division indicates the maturity style of the option, and has no relation to the geographical scope of the option.

\subsection{Determining the value of options}

Since their inception, to this day, pricing options is one of the most attractive areas of financial theory. Options are inherently quite different from other financial instruments (Soskic \& Zivkovic, 2011). As they are derivatives, they are linked to the underlying instrument. However, the application of standard discounting methods for future cash flows, which are used in determining the prices of underlying financial instruments (bonds, stocks), is not possible here. The reason for this situation is that their value depends on the value and risk of these other, basic instruments. For example, the value of stock options depends directly on the movement of stock prices. Given that these changes are frequent and large and that there is a high level of risk and uncertainty, specific techniques need to be applied to evaluate them. A large number of authors have been involved in this field, so there are many different models for evaluation (Mićović, 2003).

The binomial model is one of the simplest models for determining the value of options. It is based on the following assumptions:

- the perfection of the financial market, without disruption and transaction costs;

- interest rate risk constancy;

- the shares do not pay dividend;

- no restrictions on sale without cover, etc.

The main idea of the model is to view the movement of stock prices as a binomial process. In the process, prices at the end of one period can only move in two directions - up and down. This is a basic limitation of this model and is quite unrealistic. To be more realistic, the observation period must be shortened by 
including more options. But approaching the model in this way is greatly complicated, as the analysis is reduced to a decision tree with many alternatives (Rosse et al., 2005).

The Black-Scholes model was created precisely in response to the shortcomings of the binomial model and it also resolved some of them. Compared to the previous period, the number of periods was increased, i.e. they were shortened, which gave the model a continuous time. It was developed in 1973 and belongs to a group of models where price movements are viewed as a stochastic process of continuous time. In such processes, it is specific that changes take place at all times. Prices are assumed to follow the so-called "random walk" in their movement. In this model, this is the main reason why standard techniques for predicting expected future returns and reducing them to present value cannot be applied to options. That is why these two authors have developed differential equations that reflect the basic regularities in the movement of stock prices, and thus serve to determine the value of options. The main assumption is that stock prices follow the Winer's process, that is, they change:

$$
d P=\mu P d t+\sigma P d z
$$

Where tags have the following meaning:

$\mathrm{P}$ - share price;

$\mu$ - current expected mean value of the yield rate;

$\sigma$ - standard deviation;

$\mathrm{dz}-$ Winer's process.

Using the appropriate techniques, according to Eric (2003, p. 408-409), differential equations are derived to determine the value of options and obtain the ultimate equality:

$$
c(P, t)=P N\left(d_{1}\right)-S e^{-r T-t} N\left(d_{2}\right)
$$

Where is:

$$
\begin{gathered}
d_{1}=\frac{\ln (P / S)+\left(r+\sigma^{2} / 2\right)(T-t)}{\sigma \sqrt{T-t}} \\
d_{2}=\frac{\ln (P / S)+\left(r-\sigma^{2} / 2\right)(T-t)}{\sigma \sqrt{T-t}}=d_{1}-\sigma \sqrt{T-t}
\end{gathered}
$$

The elements of the equation are:

$\mathrm{c}(\mathrm{P}, \mathrm{t})$ - option price as a function of stock price and time;

$\mathrm{P}$ - stock price; 
T-t - maturity;

$\mathrm{S}$ - contract price;

$\sigma^{2}$ - variance in stock returns as a measure of risk;

e - natural logarithm $(2,71828)$;

$\mathrm{S} \times \mathrm{e}^{-\mathrm{rT}-\mathrm{t}}$ - discount factor, serves to reduce the contracted price to present value;

$\mathrm{N}\left(\mathrm{d}_{1}\right)$ - cumulative probability for a unit of normal variable $\mathrm{z}$. It is the probability that a random variable (stock price) that has a standard normal schedule will be smaller than size d. N(d) can be between 0 and 1 .

\subsection{The upper and lower bounds of the option price}

The price of any option ranges between the upper and lower limits of the option price. The option price can never be higher than the price of the underlying instrument, so this rule applies to the upper limit. In fact, the value of the option as an instrument conferring the right to buy the underlying instrument may in no case be greater than the value of that instrument. They will be equal in case the execution price is equal to zero, that is, the option contracted for free submission of the basic instrument. Then the value of the option will be equal to the price of the underlying instrument at a given time. Mathematical:

$$
\max (c)=[S-X]=[S-0]=S
$$

Where is: $\mathrm{S}$ - price of the underlying instrument; $\mathrm{X}$ - the exercise price of the option.

Graphically, the upper bound is a straight line starting from a coordinate beginning at an angle of 45 degrees (Figure 12), denoting the unit elasticity of the purchase option price and the price of the underlying instrument (the relative change in the price of the underlying instrument equals the relative change in the purchase option).

The lower price limit of an option is determined by its intrinsic value. The holder of the option obtains the intrinsic value of the option by exercising it, if exercise is possible at that moment. For an option that would bring the owner an immediate profit, we say that he is "in the money zone". This is the case for purchase options whose exercise price is below the current market price of the underlying instrument. With sales options, this situation is possible when the exercise price is above the current market price of the underlying instrument. Otherwise the option is said to be out of the money. When these two prices are equal, the option is said to be at the limit of profit (at the money). In the first case, the option has an intrinsic value, while the other two are said to have no intrinsic value. 
If we take the European purchasing option as an example, which in addition to its intrinsic value has a temporal value (because it can be done only on the day of maturity), the price limits look graphically like this (Marinkovic, 2011):

\section{Figure 12: Price limits of the European purchase option}

European purchasing option price

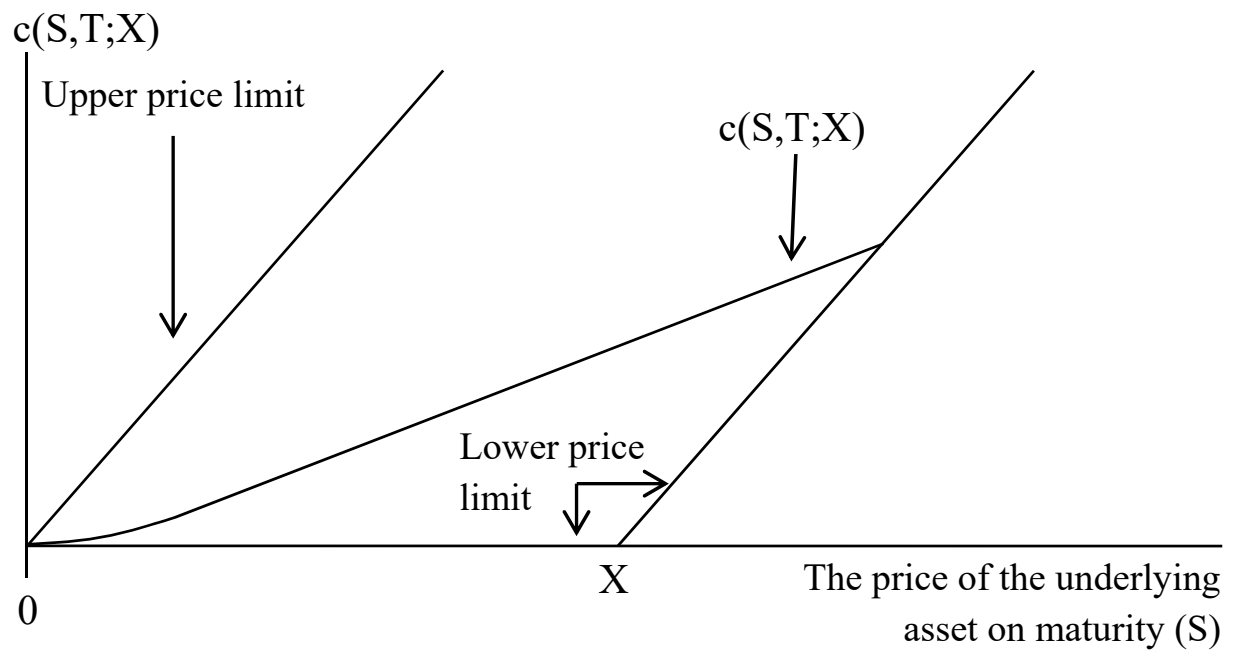

Source: Marinković, 2011 (p.380)

\section{Conclusion}

Financial derivatives have been the most significant financial innovation affecting the creation of new, very deep and broad financial markets for the last forty years. Their numbers are steadily increasing. New variants of already existing derivative contracts are emerging and thus, entities are given the opportunity to manage risks in different ways, whether they are interest rate or foreign exchange risk.

Although their legal nature is debatable, the generally accepted view is that they are contracts. There are more reasons for this. First of all, when it comes to OTC derivatives, we conclude that they are adaptable to counterparties and that the autonomy of the will (as a fundamental principle in contract law) is fully respected. It remains for the contracting parties to fulfill their obligations in the way they have been contracted. Then, in the case of stock exchange derivatives, these are highly standardized contracts, which can be called standard contracts, where all the essential elements of the contract are specified in detail. All derivatives (except options) are bilaterally binding and obligations exist for both parties. There is interdependence between obligations. The obligation of one party is the legal basis of the other party's rights, as is the right of one party the legal basis of the other party's obligation. This characteristic classifies them as derivatives of a symmetric 
position profile. Options are asymmetric derivatives. Under that contract, one party has an exclusive right, while the other party has an exclusive obligation. It can be said that these are unilaterally binding contracts.

No matter how we determine the individual derivatives, one thing is certain. Our legislator regulates them with the Law on Securities and Other Financial Instruments Market. This law defines futures and option contracts. Although their trade is legally regulated, we cannot meet them in our practice. At the moment, these instruments have not been issued or quoted on our financial market.

\section{References}

Đurović, S., Đurović, J., Đurović, M. (2011) Berze i berzansko poslovanje. Novi Sad.

Erić, D. (2003) Finansijska tržišta i instrumenti. Dejan Erić i Čigoja štampa. Beograd.

Erić, D., Đukić, M. (2012) Finansijska tržišta u uslovima krize. Institut ekonomskih nauka. Beograd

Jovanović, N. (2008). Pojam ugovora u anglisaksonskom pravu. Anali pravnog fakulteta u Beogradu 1/2008, 63-64, preuzeto sa: http://anali.ius.bg.ac.rs/A2008-1/Anali\%2020081\%20str\%20063-088.pdf, pristupljeno 2. septembar 2019.

Kuštrimović, R., Lazić, M. (2011) Uvod u građansko pravo. Gip Punta. Niš

Marinković, S. (2017) Finansijska tržišta. Ekonomski fakultet Univerziteta u Nišu. Niš.

Milenković-Kerković, T. (2009), Autonomni ugovori trgovinskog prava. Ekonomski fakultet Univerziteta u Nišu, Niš.

Milenković-Kerković, T., Spirović-Jovanović, L. (2013) Obligacije i ugovori trgovinskog prava. Ekonomski fakultet Univerziteta u Nišu, Niš.

Mićović, M. (2003) Finansijski derivati. Pravo i privreda. Beograd, 454-464.

Mićović, M. (2009) Forvard i finansijski derivati u pravu i praksi. Pravna riječ. Banja Luka, 466-472.

Pravila poslovanja Beogradske berze a.d. Beograd (2015), preuzeto sa: http://www.belex.rs/regulativa/pravila_poslovanja, pristupljeno 12. Septembar 2019.

Prednacrt Građanskog zakona (2015), preuzeto sa: http://www.paragraf.rs/nacrti_i_predlozi/260615-nacrt_gradjanskog_zakonika.html, pristupljeno 12. Septembar 2019.

Radović, M., Radukić, S. \& Njegovir, V. (2018) The application pf the Markoviwitz's model in efficient portfolio fprming on the capital market in the Republic of Serbia, Economic Themes, 56(1), 17-34

Radišić, J. (2018) Obligaciono pravo-opšti deo. Pravni fakultet, Centar za publikacije, Nišs.

Rosse S. Peter and Silvia C. Hudgins, Bankarski menadžment i finansijske usluge, Data status, Beograd, 2005.

Savić J., Veselinović, N. (2019), Measuring clients' attitudes banking services quality using the Servqual model, Economic Themes, 57(2), 201-217

Šoškić, D., Živković, B. (2011) Finansijska tržišta i institucije. Ekonomski fakultet Univerziteta u Beogradu. Beograd

Zakon o tržištu hartija od vrednosti i drugih finansijskih instrumenata, Službeni glasnik RS, broj $47 / 06$ 


\section{PRAVNA PRIRODA I ULOGA SWAP ARANŽMANA I OPCIJA KAO FINANSIJSKIH INSTRUMENATA}

Apstrakt: Finansijski derivati su, poslednjih četrdesetak godina, najznačajnija finansijska inovacija koja utiče na stvaranje novih, veoma dubokih i širokih finansijskih tržišta. Njihov broj se stalno povećava. Nastaju nove varijante već postojećih derivativnih ugovora i samim tim se subjektima pruža mogućnost da na različite načine upravljaju rizicima. Iako im je pravna priroda diskutabilna, opšte prihvaćen stav je da su to ugovori. Svop je najmlađi od svih finansijskih derivata i predstavlja finansijsku inovaciju novijeg datuma. Tržište svopova beleži jednu od najbržih stopa rasta među globalnim finansijskim tržištima. Svop predstavlja privatni sporazum između dve strane o razmeni novčanog toka na utvrđeno vreme u budućnosti i u skladu sa unapred utvrđenim obrascem. Najčešći korisnici svopova su nefinansijske korporacije, koje žele da primaju varijabilnu, a da plaćaju fiksnu kamatnu stopu u cilju ograničenja kamatnih troškova po bankarskim zajmovima ili emisijama obveznica sa varijabilnom kamatnom stopom, zatim banke, vlade zemalja i neke supranacionalne institucije, na primer Svetska banka. U ekonomskoj teoriji ističe se stav da je komparativna prednost osnov funkcionisanja svopova. Opcije su ugovori u kojima jedna strana ima isključivo pravo, dok druga ugovorna strana preuzima isključivo obavezu da kupi ili proda aktivu na koju je kreirana opcija. U nacionalnom zakonodavstvu opcijski ugovor je prenosivi standardizovani ugovor kojim kupac stiiče pravo da, uz obavezu plaćanja ugovorene premije na dan, odnosno dane dospeća utvrđene ugovorom.

Ključne reči: ugovor, finansijski derivati, svop, opcija, novčani tok

\section{Authors biographies}

Ružica Petrović graduated from the Faculty of Economics in Nis in 2013. In September 2017 she graduated bachelor academic studies at the study program Finance, Banking and Insurance. In December 2019 she completed a master academic studies at the same program, master theme titled Contractual Legal Nature and Economic Aspects of Financial and Credit Derivates. Since 2018 she started master program at the Faculty of Law in Niš.

Tamara Milenković Kerković is a Full Professor at the Faculty of Economics, University of Niš and she teaches Commercial Law and International Trade Law at the undergraduate level of study and Banking Law and Competition Law at Masters and doctoral level of study as well. Her fields of specialization include commercial conctracts, franchising law, payement protection law and consumer protection law.

Dragana Radenković Jocić works as a Full professor in a field of Business Law (Commercial Law, EU Law, Corporate Governance, EU Competition Law). She is the vice-dean for the scientific work, in period 2006-2009, as well as 2018-currently. She was managing or participating in numerous projects: She is author of four textbooks in a field of Commercial Law and Corporate Governance, in a period 2002-2019, four monographs, and more than 150 articles. 